\title{
STRATEGI PENGEMBANGAN BMT/KSPPS DI DEPOK DENGAN METODE ANALISIS SWOT
}

\author{
Dede Abdul Fatah, Ach. Bakhrul Muchtasib, Abdillah \\ Jurusan Akuntansi, Politeknik Negeri Jakarta \\ Email:dedefatah@gmail.com, bakhrul.muchtasib@akuntansi.pnj.ac.id,abdillahpnj@gmail.com
}

\begin{abstract}
Abstrak
BMT telah banyak bermunculan di Masyarakat. Dari masyarakat kota hingga di pedesaan, seperti halnya. Mereka menyisir hingga pada basis riil masyarakat. Hingga saat ini telah tercatat 900 lebih BMT telah berdiri di Depok. Namun, hanya 52 persen yang aktif. BMT harus memiliki visi dan misi untuk meningkatkan kesejahteraan masyarakat serta turut membangun tatanan perekonomian yang berkeadilan sesuai dengan prinsip-prinsip Islam. Namun, belum tercapai visi dan misi tersebut, ternyata banyak BMT yang berguguran tidak dapat menjalankan kegiatannya. Hal ini menjadi menarik untuk diteliti dan diungkap permasalahannya sehingga dapat memberikan jawaban. Dengan menggunakan metode analisa SWOT akan dapat mengungkap permasalahan BMT yang tumbang dan juga dapat mengungkap faktor kesuksesan BMT yang tetap eksis dan bahkan tumbuh besar.
\end{abstract}

Kata kunci: Formulasi, Masalah, BMT, SWOT, LKMS, Depok

\section{PENDAHULUAN}

Masalah yang dihadapi oleh BMT sebagaimana lembaga keuangan mikro lain adalah permodalan yang relatif kecil sehingga jangkauannya tidak bisa cepat meluas. Begitu juga dengan karakter usaha masyarakat kelas bawah yang perlu selalu dilakukan pendampingan sehingga membutuhkan tenaga yang cukup besar yang dapat menyita sebagian pekerjaan yang harus diselesaikan oleh BMT. Hal tersebut dapat menjadi penghambat perkembangan BMT, belum lagi hal itu akan ditambah dengan permasalahan SDM yang tidak mumpuni sehingga sulit BMT berkembang bahkan bisa collaps.

Banyak BMT yang mengalami tumbuh dan berkembang tapi tidak sedikit pula yang berhenti beroperasi, atau gagal tumbuh. Hal ini terkait erat dengan persoalan manajemen dalam mengoperasikan BMT, apakah manajemen mampu atau tidak menjalankannya. Secara umum, seringkali manajemen tidak dapat memetakan permasalahan yang dihadapinya. Bahkan keunggulan yang dimilikinya seringkali tidak tepat dijabarkan dalam program-program mereka. Bagi yang mampu memetakan permasahalannya dan menampilkan keunggulannya secara tepat mereka dapat tumbuh dan berkembang secara baik.

Sebagaimana yang diungkapkan oleh Sadrah dan Engkos dalam Dedik Irawan, dkk (2013), umumnya pendirian BMT kemudian berhenti dalam waktu yang singkat atau tumbuh tetapi kinerjanya kurang baik, dan sedikit BMT yang dapat berjalan dengan baik disebabkan tidak diimbangi dengan sumber daya manusia (SDM) yang memiliki pengetahuan, pengalaman dan keterampilan serta pengelolaan yang profesional. Fakta di lapangan menunjukkan banyak BMT yang tenggelam dan bubar disebabkan berbagai hal, antara lain karena manajemen yang kurang profesional, pengelola yang tidak amanah sehingga memunculkan 
ketidakpercayaan masyarakat. Hal tersebut memicu penarikan dana secara besarbesaran dan yang terjadi kemudian BMT mengalami kesulitan modal.

Selain kelemahan internal Baitul Mal Wa Tamwil (BMT) yang telah disebut di atas, BMT juga dihadapkan pada tantangan yang lebih berat. BMT tidak dapat lagi mengandalkan modal kepercayaannya pada sentimen masyarakat tentang isu-isu syariah, seperti keharaman riba dan sistem bunga serta menjalankan sistem ekonomi berdasarkan syariah Islam. Jika hal itu tidak dibarengi dengan profesionalitas kerja dan sikap yang amanah akan ditinggalkan oleh masyarakat. Kinerja yang baik, manajemen yang handal dan pelayanan yang memuaskan akan dibayar dengan kepercayaan masyarakat. Jika itu tidak dilakukan rentan sekali BMT ditinggalkan oleh masyarakat. Apalagi saat ini perbankan syariah nasional telah menyasar ke arah mikro. Bank syariah memiliki permodalan yang kuat relatif lebih mudah untuk mengucurkan dananya. Dari sisi keamanan pun lebih terjamin dengan segala fasilitas yang dimilikinya. Apalagi Bank Perkreditan Rakyat Syariah (BPRS) yang selama ini telah head to head dengan BMT semakin mempersempit ruang gerak BMT, karena itu mau tidak mau BMT harus meningkatkan kinerja usahanya agar mampu bersaing dan bertahan hidup.

Berdasarkan hal tersebut, untuk memberikan gambaran yang relevan terhadap perkembangan BMT, baik yang tumbuh maupun yang gagal, perlu dilakukan pengamatan dan penelitian secara mendalam dengan menganalisa permasalahan internal dan eksternal BMT. Pada permasalahan internal BMT dapat dilihat dan diteliti pada sumber daya yang dimiliki. Sumber daya yang tidak dimiliki oleh yang lain, apalagi memiliki sifat unik, dapat dikategorikan sebagai kekuatan (strength). Sesuatu yang berbeda dan dapat dijalankan dengan baik oleh BMT inipun merupakan kekuatan. Sedangkan semua keterbatasan sumber daya yang dimiliki BMT dapat menjadi faktor kelemahannya (weakness). Sementara dari permasalahan eksternal BMT dapat dilihat pada hal-hal apa saja yang melingkupinya. Permasalahan ekonomi, masyarakat, persaingan usaha dapat menjadi peluang (opportunity) bagi BMT dan dapat pula jadi ancaman (threat).

1. Faktor apa saja yang menyebabkan BMT tumbuh dan berkembang?

2. Faktor apa saja yang menyebabkan BMT gagal?

3. Bagaimana strategi BMT untuk tetap bertahan dan berkembang pesat?

\section{METODE PENELITIAN}

Penelitian ini menggunakan metode deskriptif analitis. Pendekatan yang dilakukan dengan cara observasi dan partisipasi. Data yang diperoleh dalam penelitian ini merupakan data pimer yang diperoleh melalui kuesioner dan data sekunder melalui media yang lain.

\section{Ruang Lingkup dan Obyek Penelitian}

Penelitian ini akan dilakukan civitas academica Politeknik Negeri Jakarta tahun 2015. Ruang lingkup penelitian ini akan menganalisis persepsi para Manajer BMT dari pengalaman yang mereka lalui selama menjalankan kegiatan BMT. Kegagalan dan kesuksesan di dalam menjalankan kegiatan BMT menjadi analisa studi sehingga dapat ditemukan faktor-faktor penentu atas kegagalan dan kesuksesan tersebut. Faktor kegiatan apa saja yang menjadikan BMT gagal dan faktor kegiatan apa yang menjadikan BMT sukses.

Obyek penelitian ini adalah civitas Manajer BMT di Jabodetabek. Pemilihan Manajer BMT di Jabodetabek sebagai obyek penelitian dikarenakan posisi ini merupakan posisi yang sangat mengerti dan merasakan atas kegiatan/operasional BMT. Bagaimana menjalankan BMT, mengatur dan mengelola merupakan keahlian mereka yang didapatkan langsung dari praktek pelaksanaan operasional BMT. 


\section{Populasi dan Sampel}

Menurut Suharsini Arikunto (1993: 115), populasi adalah keseluruhan subyek penelitian. Apabila seorang ingin meneliti semua elemen yang ada dalam wilayah penelitian, maka penelitian tersebut dinamakan penelitian populasi atau studi populasi atau studi sensus.

Keseluruhan pengamatan yang menjadi perhatian kita, baik terhingga maupun tak terhingga, menyusun apa yang disebut populasi. Di waktu lampau, istilah "populasi" mengandung makna pengamatan yang diperoleh dari penelitian statistik yang berhubungan dengan orang banyak. Dimasa kini, statistikawan menggunakan istilah itu bagi sembarang pengamatan yang menarik perhatian kita, apakah itu sekelompok orang atau benda apa saja. (Ronald E Walpole, 1995: 6-7).

Populasi adalah wilayah generalisasi yang terdiri dari objek atau subjek yang menjadi kuantitas dan karakteristik tertentu yang ditetapkan oleh peneliti untuk dipelajari dan kemudian ditarik kesimpulannya (Sugiyono, 2002: 57). Nazir mengatakan populasi berkenaan dengan data, bukan orang atau bendanya. Kemudian populasi adalah totalitas semua nilai yang mungkin, baik hasil menghitung ataupun pengukuran kuantitatif maupun kualitatif dari karakteristik tertentu mengenai sekumpulan objek yang lengkap (Sugiyono, 2002: 57).

Sampel menurut Suharsini Arikunto (1993: 117) adalah sebagian atau wakil populasi yang diteliti. Dinamakan penelitian sampel apabila kita bermaksud untuk menggeneralisasikan hasil penelitian sampel tersebut.

\section{Metode Analisis Data}

Metode yang digunakan dalam pendekatan ini bersifat fleksibel dan tidak terstandarisasi. Penelitian kualitatif sifatnya fleksibel, dalam arti kesesuaiannya tergantung dari tujuan setiap penelitian. Walaupun demikian, selalu ada pedoman untuk diikuti, tapi bukan aturan yang mati (Cassel \& Symon, 1994; Strauss, 1987;
Taylor \& Bogdan, 1984). Jalannya penelitian dapat berubah sesuai kebutuhan, situasi lapangan serta hipotesa-hipotesa baru yang muncul selama berlangsungnya penelitian tersebut.

Dalam penelitian ini akan menggunakan analisis SWOT yang merupakan bentuk analisa situasi dan kondisi yang bersifat deskriptif (memberi gambaran), yang menempatkan situasi dan kondisi sebagai faktor masukan, yang lalu dikelompokkan menurut kontribusi masing-masing.

Rangkuti (2008) mengatakan bahwa analisis SWOT adalah analisis untuk mengidentifikasi berbagai factor dengan cara sistematis untuk merumuskan strategi perusahaan. Analisis ini didasarkan pada logika yang dapat memaksimalkan kekuatan dan peluang, namun secara bersamaan dapat meminimalkan kelemahan dan ancaman. Matriks ini dapat menjelaskan peluang dan ancaman yang dihadapi perusahaan sehingga dapat disesuaikan dengan kelemahan dan kekuatan yang dimiliki.

Analisis SWOT terbagi atas 4 komponen yaitu: 1. Strength (S) adalah situasi atau kondisi yang merupakan kekuatan dari organisasi atau program pada saat ini. 2. Weakness (W) yaitu situasi atau kondisi yang merupakan kelemahan dari organisasi atau program pada saat ini. 3 . Opportunity (O) adalah situasi atau kondisi yang merupakan peluang diluar organisasi yang akanmemberi peluang berkembang bagi organisasi dimasa depan. 4. Threat (T) adalah situasi yang merupakan ancaman bagi organisasi yang datang dari luar organisasi dan dapat mengancam eksistensi organisasi dimasa depan.

\section{HASIL PEMBAHASAN}

1. Pengertian BMT 
Baitul Mal Wa Tamwil (BMT) terdiri dari dua istilah, yaitu baitul mal dan baitut tamwil. Baitul maal dalam bahasa Indonesia artinya rumah harta. Baitul maal lebih mengarah pada usahausaha pengumpulan dan penyaluran dana yang non profit, seperti zakat, infak dan shadaqah. Hal ini merupakan diantara keunggulan yang dimiliki BMT yang tidak dimiliki oleh lembaga keuangan mikro lainnya dalam hubungannya dengan pemberian pinjaman kepada pihak yang tidak memiliki persyaratan/jaminan yang cukup. BMT memiliki konsep pinjaman kebijakan (qardhul hasan) yang diambil dari dana ZIS atau dana sosial. Dengan adanya model pinjaman ini, BMT tidak memiliki risiko kerugian dari kredit macet yang mungkin saja terjadi.

Jadi, sebenarnya BMT memiliki semacam jaminan/proteksi sosial melalui pengelolaan dana baitul maal berupa dana ZIS ataupun berupa insentif sosial, yakni rasa kebersamaan melalui ikatan kelompok simpan pinjam ataupun kelompok yang berorientasi sosial. Proteksi sosial ini menjamin distribusi rasa kesejahteraan dari masyarakat yang tidak punya kepada masyarakat yang punya. Dengan demikian, terjadi komunikasi antara dua kelas yang berbeda yang akan memberikan dampak positif kepada kehidupan sosial ekonomi komunitas masyarakat sekitar.

Sedangkan baitut tamwil sebagai usaha pengumpulan dana dan penyaluran dana komersial untuk mengembangkan usaha-usaha produktif dan investasi dalam meningkatkan kualitas kegiatan ekonomi pengusaha kecil mikro antara lain dengan mendorong kegiatan menabung dan fasilitasi pembiayaan guna menunjang usaha ekonominya. Dalam konsep baitut tamwil, pembiayaan dilakukan dengan konsep syariah (bagi hasil). Kelebihan konsep bagi hasil adalah menyebabkan kedua belah pihak, pengelola BMT dan peminjam saling melakukan kontrol. Di sisi lain pengelola dituntut untuk menghasilkan untung bagi penabung dan pemodal.
Secara legal formal BMT sebagai lembaga keuangan mikro berbentuk badan hukum koperasi. Sementara sistem operasional BMT mengadaptasi sistem perbankan syariah yang menganut sistem bagi hasil. Sehingga, produk-produk yang berkembang dalam BMT menyerupai produk-produk yang ada di bank syari'ah. Sebagaimana yang telah di dorong oleh PINBUK, dalam menjalankan kegiatannya, peraturan operasional BMT sama halnya dalam bank syari'ah yaitu berdasarkan undang-undang Perbankan Nomor 7 tahun 1992 dengan ketentuan pelaksanaannya seperti PP Nomor 71 tahun 1992 tentang BPR serta PP Nomor 72 tahun 1992 yang mengatur mengenai bank dengan prinsip bagi hasil. Undang-undang Nomor 7 tahun 1992 kemudian diganti dengan Undangundang Nomor 10 tahun 1998 (PINBUK, Hal 6).

Meskipun demikian ia tetap harus tunduk pada Undang-undang Nomor 25 tahun 1992 tentang Perkoperasian dan PP Nomor 9 tahun 1995 tentang pelaksanaan usaha simpan pinjam oleh koperasi. Undang-undang tersebut sebagai payung berdirinya BMT (Lembaga Keuangan Mikro Syari'ah). Hal ini dipertegas oleh KEP. MEN Nomor 91 tahun 2004 tentang 17 Koperasi jasa keuangan Syari'ah. Kementerian Negara Koperasi dan UKM telah mengatur BMT secara khusus pada Keputusan Menteri Negara Koperasi dan Usaha Kecil dan Menengah No. 91/Kep/M.KUKM/IX/2004 tentang Petunjuk Pelaksanaan Kegiatan Usaha Koperasi Jasa Keuangan Syari'ah. Dengan keputusan ini, segala sesuatu yang terkait dengan pendirian dan pengawasan BMT berada di bawah Departemen Koperasi dan Usaha Kecil dan Menengah.

\section{Faktor Perkembangan BMT}

Dalam operasionalnya BMT banyak yang tumbuh dan berkembang tapi tidak sedikit yang gagal sehingga collaps. Dari beberapa penelitian telah dikemukan faktor keberhasilan dan kegagalan BMT. Diantaranya penelitian yang dilakukan oleh 
Dedik Irawan, dkk., terhadap BMT Al Hasanah Lampung telah menemukan adanya 10 faktor internal yang berpengaruh terhadap perkembangan BMT Al Hasanah yang terdiri dari 5 faktor kekuatan dan 5 faktor kelemahan. Faktor kekuatan BMT yaitu: 1) tingkat pendidikan dan keterampilan pengurus dan karyawan cukup tinggi dan profesional, 2) sarana dan prasarana BMT cukup memadai, 3) pengurus sangat disiplin, 4) penggunaan modal yang efektif dan 5) produk pelayanan sangat membantu anggota. Faktor kelemahan yaitu: 1) anggota yang kurang memahami konsep syariah, 2) kondisi gedung yang sempit, 3) masih adanya biaya administrasi, 4) modal yang dimiliki koperasi tidak besar, 5) tidak semua anggota dapat menikmati produk pelayanan.

Sementara 10 faktor eksternal, yaitu: Peluang: 1) tersedianya modal dari pihak ketiga, 2) BMT menganut sistem bagi hasil, 3) peraturan pemerintah yang mendukung BMT, 4) sebagian besar masyarakat setempat pedagang, 5) teknologi transfer online. Faktor acaman yaitu, 1) modal sebagian besar dari pihak ketiga, 2) kenaikan harga BBM, 3) belum adanya undang-undang yang mengatur konsep syariah, 4) masyarakat tidak mengerti mengenai konsep syariah dan konvensional, 5) biaya pengadaan yang tinggi. Berdasarkan strategi prioritas diperoleh tiga alternatif strategi prioritas tertinggi yaitu, a) meningkatkan kualitas pelayanan, b) pengurus dan karyawan memiliki tingkat pendidikan yang tinggi c) adanya kerjasama dengan instansi pemerintah maupun swasta.

Penelitian yang dilakukan oleh Lia Syukriah Sa'roni terhadap BMT Berkah Madani Cimanggis memaparkan faktor keberhasilan BMT yang dilihat dari sisi analisa keuangan, analisa risiko, karakteristik nasabah, value dan attitude, dan analisa sistem support bisnis, telah menghasilkan beberapa faktor diantaranya kemampuan dalam mengelola keuangan, karakteristik nasabah, kemampuan mengelola risiko, hubungan kedekatan BMT dengan nasabah dan sistem IT yang memadai menjadi faktor utama keberhasilan BMT Berkah Madani tumbuh dan berkembang dengan baik.

Sementara Marissa Grace Haque dalam Analisa Strategi LKM Syariah NonBank telah mengidentifikasi beberapa faktor yang menjadi kekuatan, kelemahan, peluang dan ancaman BMT. Dari sisi kekuatan terdapat 1) BMT memiliki reputasi terjaga baik, 2) BMT memiliki manajemen sederhana namun solid, 3) BMT mandiri karena tumbuh dan berkembang dari-oleh-untuk masyarakat di sekitarnya sendiri, 4) BMT sangat paham kebutuhan pasar yang syariah, 5) BMT sangat paham karakteristik krediturnya, 6) BMT punya kemudahan proses dibanding dengan perbankan konvensional, dan 7) BMT fokus pada usaha mikro kecil menengah. Kelemahannya 1) BMT kurang modal pengembangan bisnisnya, 2) BMT sering memiliki SDM yang kurang handal, 3) BMT sangat kurang promosinya, 4) Produk pelayanan BMT masih terbatas, 5) Belum ada shared data base berbasis IT terhadap kreditur kriminal, 6) Banyak kasus BMT yang tidak tuntas karena kemampuan terbatas para penegak hukum, dan 7) Belum ada kepastian hukum dalam bentuk UU yang mampu melindungi hak-kewajiban BMT.

Sedangkan dari sisi peluang dipengaruhi oleh faktor 1) Mayoritas penduduk Indonesia beragama Islam, 2) BMT tidak terimbas oleh krisis moneter, 3) BMT telah terbukti ketangguhannya dan memiliki pasar yang fanatik atau captive market, 4) BMT membantu program Pemerintah secara tak langsung, 5) Sebagian besar masyarakat Indonesia berada pada strata ekonomi UMKM, 6) Sistem lembaga keuangan syariah tidak terimbas krisis moneter, dan 7) Sistem lembaga keuangan syariah paling pas untuk golongan masyarakat pada strata ekonomi ini.

Ancaman BMT ini terdapat pada 1) Dampak persaingan dengan lembaga 
keuangan internasional kepada lembaga keuangan nasional, 2) Masuknya perbankan syariah bermodal besar milik non-muslim yang memberi biaya pinjaman sangat murah karenamampumencapai economic of scale, 3) Situasi politik dan keamanan dalam negeri yang tidak stabil, 4) Peraturan perundangan Indonesia yang belum memihak pada BMT, 5) Belum ada shared data base kreditur kriminal, 6) Kesepakatan Indonesia pada WTO dan ACFTA serta menyusul BRIC, dan 7) Perkembangan teknologi yang sangat pesat (dalam kaitan pelayanan ATM, SMS, internet Banking).

\section{Masalah Perkembangan BMT di Depok}

Dalam penelitian dengan analisis SWOT ini telah menggambarkan kekuatan, kelemahan, peluang Baitul Mal wa Tamwil (BMT). Identifikasi terhadap komponen swot dapat dijadikan sebagai dasar dalam pemilihan strategi yang perlu dikembangkan dalam pengelolaan zakat. Sehingga akan mendapatkan hasil yang mendekati permasalahan dalam pengembangan.

Rangkuti (2008) mengatakan bahwa analisis SWOT adalah analisis untuk mengidentifikasi berbagai factor dengan cara sistematis untuk merumuskan strategi perusahaan. Analisis ini didasarkan pada logika yang dapat memaksimalkan kekuatan dan peluang, namun secara bersamaan dapat meminimalkan kelemahan dan ancaman. Matriks ini dapat menjelaskan peluang dan ancaman yang dihadapi perusahaan sehingga dapat disesuaikan dengan kelemahan dan kekuatan yang dimiliki.

\section{a. Hasil Analisis SWOT}

Permasalahan pengembangan Baitul Maal wat-Tamwil/Koperasi Simpan Pinjam dan Pembiayaan Syariah di Depok didasarkan pada analisis SWOT dapat dikelompokkan pada dua bagian permasalahan, yaitu permasalahan internal (dari dalam) dan permasalahan eksternal (dari luar). Adapun permasalahan tersebut adalah:

Permasalahan Internal

1. Ketersediaan dan Kualitas Sumber Daya Manusia

2. Profesionalitas SDM

3. Sistem pendidikan dan pelatihan (regenerasi)

4. Kualitas Manajemen

5. Ketersediaan Infrastruktur Kerja

6. Ketersediaan modal

7. Inovasi produk

8. Pemanfaatan dan penggunaan teknologi dan sistemi Informasi (TI)

9. Sosialisasi dan promosi

Permasalahan Eksternal

1. Regulasi

2. Pengawasan dan pembinaan pemerintah

3. Persaingan antar koperasi dan lembaga keuangan lainnya

4. Pengetahuan dan pemahaman masyarakat tentang BMT/KSPPS

5. Kepercayaan masyarakat

6. Sistem kordinasi dan Jaringan antar BMT/KSPPS

7. Lembaga penjamin simpanan

\section{b. Strategi Pengembangan Baitul Mal wa Tamwil}

Strategi terbaik dalam pengembangan BMT adalah dengan memaksimalkan aspek kekuatan dan peluang yang didasarkan atas pertimbangan aspek kelemahan dan ancaman bagi BMT. Dengan mempertimbangkan semua aspek tersebut akan didapatkan strategi yang komprehensif untuk pengelolaan zakat di Indonesia.

Dengan melihat semua aspek dalam analisis SWOT tersebut serta hasil yang diperoleh Baitul Mal wa Tamwil dapat menerapkan strategi, diantaranya: 
Strategi untuk penyelesaian permasalahan internal:

1. Kerjasama dengan lembaga pendidikan

2. Pelatihan intensif

3. Penerapan sistem reward dan punishment

4. Perluasan struktur manajemen organisasi

5. Melengkapi sarana prasarana kerja

6. Linkage program dengan lembaga keuangan lain

7. Meningkatkan skill SDM (diklat) dan pemanfaatan IT

8. Kolaborasi membuat sistem IT atau sistem dari pemerintah

9. Memanfaatkan saluran online

Strategi untuk menyelesaikan permasalahan ekternal:

1. Penerbitan UU Koperasi/koperasi syariah

2. Memperkuat peraturan pengawasan pemerintah

3. Meningkatkan fungsi DPS Koperasi

4. Membuat LPS Koperasi

5. Meningkatkan sosialisasi dan edukasi)

6. Meningkatkan layanan dan promosi)

7. Meningkatkan kerjasama antar BMT/KSPPS)

8. Meningkatkan teknik pemasaran)

\section{SIMPULAN}

Hasil penelitian menunjukkan kekuatan dan peluang bagi BMT tetapi juga mendapat tantangan dari kelemahan dan hambatan yang muncul. Berdasarkan analisis SWOT ini BMT dapat mengembangkan strategi yang memanfatkan pada kombinasi kekuatan, peluang, kelemahan, dan hambatan. Terutama kombinasi yang dihasilkan dari kekuatan dan peluang pengelolaan zakat bagi BMT.

Diantara kesimpulan yang penting untuk disampaikan adalah; BMT/KSPPS membutuhkan payung hukum yang kuat, seperti kebutuhan penerbitan undangundang koperasi syariah. undang-undang itu pun harus bersahabat dengan BMT/KSPPS, atau harus menyesuaikan kebutuhan mendasar dalam perkembangan BMT/KSPPS.

Tidak kalah pentingnya adalah ketersediaan sumber daya manusia yang handal yang memahami seluk beluk perkoperasian dan permasalahan ekonomi masyarakat kelas bawah, sebagaimana target pasar BMT. Minimnya pemahaman SDM tentang BMT perlu dilakukan kegiatan pelatihan intensif kepada karyawan, terutama karyawan baru. Pelatihan dapat dilakukan secara langsung (on the job training) atau dengan cara tidak langsung/pelatihan diluar kantor (off the job training).

Disarankan bagi BMT secara aktif melakukan sosialisasi dan edukasi ke masyarakat tentang pengelolaannya. Sehingga dapat memberikan pemahaman kepada masyarakat. Hal ini akan mendorong minat masyarakat bertransaksi dengan BMT.

Kemudian pemanfaatan atas teknologi yang berkembang dengan tujuan memberikan kemudahan dalam layanan transaksi dengan memanfaatkan teknologi digital. Hal ini untuk membangun kepercayaan masyarakat terhadap BMT.

\section{DAFTAR PUSTAKA}

Cassell, C.; Symon, G. (1994). Qualitative Methods in Organizational Research. London : Sage

Dedik Irawan, Muhamad Irfan Affandi, Umi Kalsum. (2013). Analisis Studi Pengembangan LKMS Pedesaan (studi Kasus BMT Al Hasanah Sekampung), Jurnal JIIA 
Marissa Grace Haque (2011). Analisis Strategi LKM Syariah Non-Bank, Membangun Gerakan BMT Indonesia

Rangkuti, Freddy JP (2006) Analisis SWOT Teknik Membedah Kasus Bisnis. Jakarta: PT Gramedia Pustaka Utama

Sa'roni, Lia Syukriah (2010). Analisa Faktor-faktor Yang Mempengaruhi Keberhasilan BMT Berkah Madani Cimanggis, UIN Syarif Hidayatullah Jakarta
Strauss, A. L. (1987). Qualitative Anaysis for Social Scientists. New York : Cambridge University Press

Sugiyono (2004). Metode Penelitian Bisnis, Cetakan Keenam, Bandung, Alfabeta.

Taylor, S. J.; Bogdan, R. (1984). Introduction to Qualitative Reserach Methods : The Search for Meaning (2nd ed.). New York : John Wiley \& Sons Walpole, Ronald (1995), Pengantar Statistika, Edisi Ketiga, Jakarta, PT. Gramedia Pustaka Utama. 